\title{
Colonial Architecture or Relatable Hinterlands? Locke, Nandy, Fanon and the Bandung Spirit
}

\section{Introduction}

[T]hey were not actors. They had been chosen; or they themselves had chosen their roles in this sacred story that would go on for nine afternoons over a two-hour period till the sun set. They were not amateurs but believers ... They believed in what they were playing, in the sacredness of the text, the validity of India, while I, out of the writer's habit, searched for some sense of elegy, of loss, even of degenerative mimicry in the happy faces of the boy-warriors or the heraldic profiles of the village princes. I was polluting the afternoon with doubt and with the patronage of admiration. I misread the event through a visual echo of History - the cane fields, indenture, the evocation of vanished armies, temples, and trumpeting elephants - when all around me there was quite the opposite: elation, delight in the boys' screams, in the sweets-stalls, in more and more costumed characters appearing; a delight of conviction, not loss. The name Felicity made sense. ${ }^{1}$

The writer is the St Lucian poet Derek Walcott, and Felicity is a small village in Trinidad that lies within the borough of Chaguanas, so named after the Carib tribe of that area. Walcott has come across a hinterland populated by one set of historically transplanted peoples. Walcott catches himself contaminating the hinterland with a colonially induced scepticism, and he asks why could it not be the case that these people in the cane fields of Trinidad could blissfully inhabit India? No doubt, if Walcott walked some way over the hills he might chance upon another hinterland populated by descendants of a different set of forcibly displaced peoples. They would be chanting sacred texts around a fire accompanied by "harps" (drums) affirming, this time, the validity of Africa. There would be joy in their hearts, too. And there would also be a sense of conviction, in this instance, that the evil of their crossing over the 
Atlantic still had to be exorcised. One of their members might rise and proclaim something along these lines:

For from I start I no fe stop till I see the place mash dung 'cause our determination is as Babylon! An' da's why Nyahbinghi Order a one Order fe bruck dung Babylon wall yuknow. Da's why yu chant an' chant an' never stop chant 'till you hear Boo boo boo boom!!!!!

Another Caribbean poet, Édouard Glissant, speaks of these hinterlands. ${ }^{3}$ They have their origins as geographical places of maroonage (hills and forests beyond the plantation complex) but over time they might become ancestral grounds. ${ }^{4}$ Their spatiality is constituted not just geographically but socially, linguistically, psychologically in so far as hinterlands protect people from - or simply defer the moment of - being terminally incorporated into colonial rule. In fact, the constitution of hinterlands might vary greatly in terms of time and place. It is a specific kind of hinterland that Walcott comes across in Felicity, one wherein the text of India still retains a geographical grounding. But hinterlands might be retained even when their geographical mooring is entirely uprooted. Then hinterlands become subversively mobile; their spatial seedbed is in the psyche and its community coordinates, and so these hinterlands can suddenly manifest around a camp fire, a portable tabernacle, or even within a drum circle when Babylon is chanted down.

John Locke would not understand this notion of hinterland. To him, anything outside of the rule of propertied "freemen" would be termed wilderness. Locke is the exemplary architect of colonial rule. As envisaged by Locke, this rule is dispensed, centrally, from the master's house and radiates outwards in myriad directions to ensnare and enclose various aliens, subalterns and their land and labour. Locke closes the colonial frontiers and drags all of them out of their various hinterlands to serve the master in his pursuit of accumulation. Ashis Nandy and Frantz Fanon resist this pull. They side, in a critical fashion, with those who live through the epics of India and the chants to Africa-Zion. However, Nandy and Fanon's projects emanate from different positions vis-à-vis Locke's architecture; they engage with different hinterlands, differentially situated vis-à-vis colonial rule, and this leads Nandy and Fanon to 
cultivate different ethos through which to dismantle the architecture of the master and redeem a space for living other-wise.

I wish to present my engagement with Locke, Fanon and Nandy as a thought piece that will allow us to critically evaluate the fate of Bandung and reconsider the prospects of its decolonial spirit. The Asian-African conference held in Indonesia in 1955 has long been a touchstone for academic engagements with colonialism, decolonisation and postcoloniality. ${ }^{5}$ Enunciating anti-colonialism and anti-racism as key policies for the transformation of global order within the Cold War world, and using the instruments of "neutrality" and "non-alignment", the Bandung conference is often said to have announced the arrival of the Third World solidarity movement. In contrast to the contemporaneous US dominated South East Asia Treaty Organization (SEATO), the Bandung conference marked the diplomatic arrival on the Cold War stage of (post)colonized peoples relating to each other without the mediation of past masters. ${ }^{6}$ Claiming to represent the majority of humanity, this movement promised to generate alternative futures arrived at through the principles of equality over hierarchy, peace over war, cooperation over conflict, and self-determination over dependency. ${ }^{7}$ Through this "spirit of Bandung" the hinterlands of the (post)colonized proposed to break free from the global architecture laid by the colonizer.

Yet as Robert Vitalis has recently argued, to take the heroic intervention of Bandung at face value is to court Third World romanticism at the expense of the historical record - the conference was not strictly non-aligned and neither was it guided by a global race consciousness. ${ }^{8}$ Moreover, as a number of postcolonial authors have noted, the paradox of the conference was that it took the key method of self-determination from blueprints of the masters' architecture: the enabling institution was to be the nation-state; and the process was to be "development" or "modernization". ${ }^{9}$ Internal hinterlands would be laid bare and the colonial frontier finally closed by postcolonial elites. What is more, some of the new independence leaders then began to use violent methods similar to those deployed by old colonial masters. ${ }^{10}$

The fate of the Bandung spirit therefore exposes the postcolonial predicament: (how) can one orient towards decolonised futures; (how) can the logic of coloniality 
be broken without its reproduction/reiteration, and (how) is it possible to cultivate and defend a space that is ordered other-wise to colonial architecture? Presently these questions seem almost naive in light of the 2005 retrospect of Bandung, convened by original participating states, many of which are now almost fully integrated into - and in some cases key players in - the globalisation of Locke's architecture. ${ }^{11}$

If, as Walcott intonates, History is to be understood as a colonial-modern episteme that maps the past by following principally the cause and effect of masters, ${ }^{12}$ then the effect of Bandung has long dissipated (if it was ever even an effect). But alternatively, as Mustapha Pasha argues, the past can also be present as memory, and in this respect, Bandung might remain subversively alive as a promise of "subaltern solidarity forged through anti-colonial struggle". ${ }^{13}$ Memory is not strictly sequential and, unlike History, can act as a generative seedbed of relationality. In this respect, Bandung would remind us that (post-)colonized peoples might want to cultivate relatable hinterlands - physical and/or psychical - in pursuit of global designs otherwise to the architecture of colonial rule. In the Historical present, Bandung has been complicit in closing the frontiers, dragging natives out of their hinterlands into the global architecture of postcolonial rule. But in the remembered present, Bandung marks the possibility of the peoples of these hinterlands cultivating decolonial relations besides and other-wise to postcolonial architecture. Hence, the History of Bandung affirms a postcolonial fate and the death of its spirit. But in the Memory of Bandung the spirit continues to enliven what Walter Mignolo has termed a "decolonial option". 14

In this article I critically enliven the Memory of Bandung through my discussion of Locke, Nandy and Fanon. I will first lay out the colonial architecture that Locke constructs around the master's - or "freeman's" household and its attendant relationships to "natives" and "negro slaves". (These are terms that are consonant with Locke's vision and as heuristic devices I do not write them in quotes nor do I claim any anthropological validity on their behalf.) Then I will turn to Nandy and Fanon. Mindful of the challenges of postcoloniality, I will emplot both of their intellectual projects within Locke's architecture so as to apprehend the ways in which they attempt to dismantle the freeman's order and the degree to which they consider it possible to redeem the hinterlands of the colonized, especially in their psychical 
constitution. However, I shall also argue that both Nandy and Fanon fall short of redeeming relatable hinterlands. Nandy focuses on the hinterlands that might be associated with the native, and he is known for his articulation of subversion of the freeman's rule as a practice of radical reconciliation. Fanon focuses on the hinterlands that might still be available to the negro slave, and he is famous for his articulation of subversion practiced as exorcism of the freeman. Both, however, forgo the cultivation of a dialogical relationship between the native and the slave.

Only rarely are the praxes of Nandy and Fanon placed in meaningful dialogue. ${ }^{15}$ In constructing such a dialogue in the shadow of Locke's freeman I intend to enliven the Memory of Bandung and its promise of anti-colonial solidarity with a decolonial impulse. In an era where the logic of coloniality has been re-globalized as neo-liberal capitalism, critical thought on the postcolonial predicament risks becoming accomplice through an epistemic obsession with the self/other master/subaltern (non-)relation. As a thought piece, then, the aim of this article is to consolidate a problematique of decolonial thought as the critical retrieval of relatable hinterlands. In this way, I hope that the article helps to redeem the spirit of Bandung against the melancholia of postcolonial history.

\section{Locke's architecture of colonial rule}

The more recent acknowledgement of the central importance of colonialism and slavery in Locke's writings significantly qualifies the older leftist contextualization of his thought vis-à-vis primitive accumulation in England and the concomitant rise of capitalism. ${ }^{16}$ Locke cognitively works out the rights and obligations of primitive accumulation by reference to the specific rights and obligations of colonialism, and as part of the broader colonizing and proselytizing project that the English crown is embarking upon in earnest. This is the world that Locke's freeman inhabits within an architecture that permits various inscribed relationships to natives and negro slaves. The foundation of Locke's architecture is a justification and securing of the political rule of propertied men in a form consonant to the property-owning rights that they enjoy under English common law. 
For this purpose, Locke defines political rule in classical sovereign terms as the power to make laws with the consequence of death. ${ }^{17}$ He claims that such sovereign power should not be devoted to the maintenance of royal prerogative and privilege, but rather to the "regulating and preserving of property". ${ }^{18}$ Locke frames his argument as a critique of Robert Filmer, who makes an argument for a divine (Adamic) patriarchal authority of royalty over freemen. Against this authority, Locke claims instead that the original condition of all humanity is to be "free from any superior power on earth", especially, to be under "no dominion of any will" save for legislative arrangements entered into by free consent. ${ }^{19}$ Reason dictates that "all being equal and independent, no one ought to harm another in his life, health, liberty or possessions". ${ }^{20}$ And because there is no original title to dominion over creation, its objects, for Locke, form part of a common stock.

There is, however, one exception: "every man has a property in his own person". This exceptionalism produces a further claim: that once man mixes his labour with an object in the common stock, he rightfully possesses that object privately and absolutely. ${ }^{21}$ The basis of rights, and what enables freedom to be actualised, is, then, possessive accumulation. I say "possessive", because unlike his contemporaries such as Grotius, Locke does not require individual property ownership to rest on the consent of anyone else. ${ }^{22}$ It is not, then, political hierarchy which for Locke justifies the accumulation of property by freemen but the law of nature; political society might or might not reasonably accord to this law. Furthermore, the constitution of the state of nature is represented by Locke most acutely in the wildernesses of America: ${ }^{23}$

[t]he fruit, or venison, which nourishes the wild Indian, who knows no enclosure, and is still a tenant in common, must be his, and so his, i.e. a part of him, that another can no longer have any right to it. ${ }^{24}$

In this respect, Locke does not erect political society in order to decompose the state of nature: they are, for him, contemporaneous arenas with empirical - and global reference points. 
Locke's architecture includes one more arena of rights and rule - that of the pater familias. Ron Becker has shown that Locke's category of "free - man" relates to the basic common law compact made after the legal end of serfdom in England, while in distinction, Locke's category of "freeman" represents those who are specifically empowered to form a government, i.e. those who enjoy political rights and representation by virtue of being propertied men of independent means. ${ }^{25} \mathrm{It}$ is hard to glean in Locke's political philosophy a strong structural line of argumentation that explicates the transformation from (natural) free - man to (political) freeman. I would argue that this is because the purpose of common law, as it developed during the long decades of English enclosure, was to provide a via media between, on the one hand, the protection of inherited property and the associated paternal order through which society was fundamentally constituted, and on the other hand, the freedom (against monarchical orders) to utilize and even alienate one's private property as one saw fit. ${ }^{26}$ In short, Locke's freeman is specifically an inheritor: he is already propertied and already a pater familias.

Locke manages to interlock the paternal constitution of the freeman with natural law and political society by separating the household of the pater familias from the palace of the monarchy. To underline this distinction, Locke makes the claim that women have as much natural dominion over their children as fathers. ${ }^{27}$ Therefore, unlike monarchical rule, the pater familias does not exercise political - sovereign powers of life and death over his wards. ${ }^{28}$ Furthermore, Locke suggests that the first (non-political) society was between man and wife, then parents and children, which "in time" began the master and servant relationship. However, all of these paternal relationships came short of the sovereignty demanded by political society. ${ }^{29}$ By this reasoning, the freeman's right to possessively accumulate objects out of the common stock extends to the labour of all who are encompassed within the authority of the pater familias. This is why Locke can state - ostensibly against the law of nature that "the grass my horse has bit; the turfs my servant has cut; and the ore I have digged ... become my property, without the assignation or consent of anyone."30

In sum, Locke places the right to possessive accumulation held by the freeman within a threefold interlocking architecture covering home and abroad: the state of nature, the household of the pater familias, and political society. It is a global vision 
of colonial incorporation wherein the rest of humanity finds itself differentially placed within and variously excluded from these arenas.

What moral arguments might justify the unique privileges of the freeman? Locke claims that the purpose of possessive accumulation, as ordained by God, is "to subdue the earth, i.e. improve it for the benefit of life". ${ }^{31}$ And to improve nature requires the observance of private property rights. Famously, Locke compares 1000 acres of "wild woods and uncultivated waste" in America to 10 acres of enclosed land in Devonshire. In the former, natives have yet to instantiate property rights concordant to possessive accumulation, and so even their patriarchs live in more wretched conditions than the servants of England. ${ }^{32}$ The "success" of possessive accumulation at home, through enclosures, legitimises the same procedures abroad, through colonialism.

Nevertheless, Locke acknowledges that, with few commons now left in England, there is little opportunity for freemen to exercise their right to possessive accumulation. ${ }^{33}$ And he notes that the invention of money in England has even led to the valuing of property by tacit agreements which have tended to encourage even larger possessions by some men. ${ }^{34}$ This is a problem for Locke, whose use of natural law against monarchical rule requires a reconciliation of the limitless accumulation with an egalitarian ethics that ensures all freemen can reap their just rewards. He finds a solution, once more, through colonial expansion. Locke points out that wilderness still exist in those parts of the world whose inhabitants have not consented to the use of money. ${ }^{35}$ His famous proclamation, "in the beginning all the world was America" ${ }^{36}$ is therefore not so much a reference to a primeval past as it is an invitation for freemen to exercise their natural right of possessive accumulation in the colonies with their expanding frontiers. ${ }^{37}$

But what of the non-propertied - the free - men? Here Locke justifies the machinery of possessive accumulation not so much via improvement but through the teaching of industriousness. "God", proclaims Locke, "gave [the world] to the use of the industrious and rational, (and labour was to be his title to it;) not to the fancy or covetousness of the quarrelsome and contentious." 38 Industriousness speaks to Locke's Puritanical ascetic translated through natural law. Indeed, Locke attributes 
the rise of the poor in England not to the consequences of enclosure, i.e. the creation of unemployment as a social ill, but to the "relaxation of discipline and corruption of manners". ${ }^{39}$ For Locke, "virtue and industry [are] as constant companions on the one side as vice and idleness are on the other"; hence the poor have to be returned to "some sense of" religious instruction in order to be trained into industriousness. ${ }^{40}$

To facilitate this project Locke again turns to the colonies, this time through his proposal on reforms to the poor laws in England. Those poor who beg within maritime counties should forcibly be made to serve for a period in the navy. ${ }^{41}$ And those who consistently take part in vice should be transplanted to the plantations. ${ }^{42}$ Indeed, there is something about the supposed pristine nature of the colonial enterprise that invokes in Locke a proselytizing fervour. ${ }^{43}$ In effect, is in the colonies that he can politically proclaim what he can only propose philosophically in England. Locke approaches the colonial enterprise as a mission spirituelle. ${ }^{44}$ The right of the freeman to possessive accumulation also brings with it a responsibility to save and civilize humanity at large.

I will now detail how particular subalterns are positioned vis-à-vis the freeman in Locke's three interlocking arenas - the state of nature, house of the pater familias and political society - and how he justifies their differentiated positioning in the overall architecture through an ideology of improvement/industriousness. In this endeavour I am influenced by the work of Barbara Arneil, although my purposes differ somewhat. ${ }^{45}$

Locke places the servant under the protective covering of nature as a free man. However, even if enjoying a formally contractual relationship, the servant falls under the authority of the paternal order of the contractor. ${ }^{46}$ Whilst this means that the master has no sovereign authority over the servant in terms of life or death, the master is morally obliged to perform the responsibilities of his paternal authority. In light of his comments on poor law reform, these responsibilities, for Locke, primarily consist of using discipline to raise the character of servants by educating them in the (economic and religious) virtue of industriousness. ${ }^{47}$ 
When it comes to American natives, Locke treats them similar to servants and places them also within the state of nature because they display basic reason; i.e. they too are free - men. ${ }^{48}$ For this reason, natives cannot be enslaved. However, unlike servants, in the absence of a consensual contract, natives cannot be forcefully dispossessed of the fruits of their labour. Nevertheless, because natives believe in a God, they have at least the potential to join political society. So Locke invokes the practice of tolerance in order to regulate the relationship between natives and freemen and also to bind the former to the latter in a paternal order (through contract) or colonial political society (via consent). ${ }^{49}$ Yet Locke values tolerance only in instrumental terms; the discourse that is facilitated by tolerance will acquaint "heathens" with "the truth and reasonableness of [Christian] doctrines." ${ }^{\text {" Of }}$ this, Locke is supremely confident. ${ }^{51}$ And if natives do not disavow their own faiths and do not incorporate themselves into the paternal body of Christ, then they can no longer be considered to be rational beings, and thus would lose their status of free - men under Locke's natural law. Just like the Spanish Requerimiento, then, Locke's mission spirituelle allows for the possibility of genocide in the long run.

Moreover, even in the immediate present, natives - as free - men - have no prior claim to sovereignty or proprietorship over their already inhabited lands and already regulated resources. For Locke the matter is not adjudicated by generic evidence of techniques of production, but rather, of improvement via possessive accumulation evidenced by private property rights. Additionally, Locke does not even classify the ceremonial form of exchange practiced by natives (Wampompeke) as a form of money exchange. ${ }^{52}$ Hence, unlike in England, natives in America run the moral risk of greed - their accumulated properties cannot be transformed into money and will therefore spoil. Despite being tolerated, then, natives can be immediately, rightfully and legally disposed of the lands and resources that they inhabit.

\section{Locke's positioning of negro slaves vis-à-vis English freemen is} perhaps the most contentious and confounding aspect of his entire architecture. As I have noted, Locke's key device for justifying rule of and by freemen in the face of monarchical "slavery" (he uses this term) is to claim the natural freedom of all humans and the impossibility of voluntarily giving oneself up to enslavement. There is, though, one circumstance in which Locke believes this to be permissible, and that 
is with respect to those who, being captured in war, would consent to the "absolute dominion and arbitrary power of their masters" rather than being put to death. Such individuals rationally forfeit their natural status as free men for the sake of survival. ${ }^{53}$ Slaves cannot, therefore, take part in possessive accumulation as they cannot own property. Moreover, the paternal order to which they forfeit themselves in this peculiar instance overlaps directly with political order in so far as the master holds the sovereign power of life or death over them: the pater familias is a pater familias rex. In this key respect negro slaves differ to natives (and servants).

Locke derives his "war captive” argument from Grotius's adoption of Roman law. However, Locke tempers this law by refuting the assumption that the right of dominion applies to the offspring of captive slaves. ${ }^{54}$ Nevertheless, Locke makes a "glaring exception" when he allows for the inherited dominion over slaves gained by purchase rather than by war. ${ }^{55}$ The fundamental constitutions of Carolina - the drafting of which Locke significantly contributes to - state that "every freeman of Carolina shall have absolute power and authority over his Negro slaves, of what opinion or religion soever". ${ }^{56}$ And unlike with case of the native, not even the civilizing force of Christian conversion will deliver them into the domain of natural law and grant them status as free men. ${ }^{57}$

To finish this section let us now revise Locke's architecture, which binds servants, natives and negro slaves to the freeman. Improvement and industriousness provide the moral justification for possessive accumulation by freemen, who enjoy natural freedom, paternal authority and political authority. Natives are positioned outside of the political authority of freemen. But while they enjoy natural freedom they cannot rightfully be said to enjoy political authority over the lands and resources that they already inhabit for their subsistence. If they use their reason properly, and by virtue of the tolerance exercised by freemen, they could become incorporated into political society, there to learn through industriousness how to become good servants in the house of the pater familias. If they do not use reason properly and assimilate to the political, moral and spiritual order of freemen, they run the potential of being abjected from the natural and political order. Negro slaves are already abjected from natural law. They are positioned solely under the authority of the pater familias who in this case is also the despotic sovereign: the pater familias rex does not tolerate the 
negro slave. Slaves can never escape this unfreedom, neither by material procreation nor by spiritual conversation.

In these ways, Locke recognizes natives and negro slaves only to outlaw their hinterlands as wilderness or as outside of natural law thus closing the frontier and dragging them into the architecture of colonial rule. Moreover, in Locke's writings, natives and slaves are segregated from each other both before they are incorporated into his architecture and in the act of incorporation itself. Before incorporation they occupy different domains - the native is situated within natural law, the slave without. Having been incorporated, the native might become a good servant to the freeman perhaps even an aspiring pater familias - yet the negro will always be under the freeman's absolute dominion. Thus all particular routes converge on the freeman's household; these hinterlands are not relatable, they cannot cross in solidarity.

\section{Nandy, Fanon and the possible hinterlands of natives and slaves}

Let us now examine how Nandy and Fanon confront Locke's global project. For this purpose I will read Nandy as subverting Locke's proposed relationship between the freeman and native, and Fanon as subverting the relationship between the freeman and the negro slave. And I will critically inquire into the extent to which their subversions conceive of the hinterlands as relatable.

For Nandy, tradition can be considered a hinterland that displaces the "enlightenment mission" of modernity, i.e. the mission spirituelle proselytised by the colonizing freeman. ${ }^{58}$ Nandy famously proclaims that "India is not the non-West; it is India" ${ }^{59}$ With this, he diffuses Locke's wild horizon in order to glean the spaces of tradition that predate the arrival of the colonial freeman and which continue to retain some kind of integrity during colonial rule. Nandy even subverts the freeman's eschatology with the viewpoint from these hinterlands: God has not ordained the world to the use of "the industrious and the rational"; indeed, the freeman is not even an "the all-important intruder" but only a transient ruler possessed by "illusions of permanence". ${ }^{60}$ Moreover, it is not wilderness that is penetrated and conquered for God's kingdom by freemen, rather, it is the freeman's household that is surrounded by 
a "definite presence of traditions, living vibrant and besieged but constantly threatening to rebound."

Nandy then turns to those natives who have decided to become good nativeservants, perhaps even aspirant pater familias. These peoples, who live urbanely and who may wish to live even more intimately with the pater familias, also feel themselves besieged by the traditions of the hinterlands. ${ }^{62}$ Seeking to leave the villages for the urban both physically and psychically they - and their descendants especially - dull the pain of crossing thresholds through a fear of nostalgia for village life and/or a radical vision of a transplanted future. ${ }^{63}$ In defence, these good nativeservants - perhaps even apprentice pater-familias - attempt to colonize the texts of hinterland India by selecting out of them what might pass as compatible with the mission spirituelle of the colonial freeman ${ }^{64}$ However, many untrained natives seem to wilfully defer or diffuse such comparisons in their own use of the texts of India, and this produces within the native-servants a "deep fear of democracy." 65

Nandy's work focuses on this aspirant group of natives mainly because he positions himself not just as an "urban, middle-class Bengali babu" but, effectively, as a traitorous native-servant. ${ }^{66}$ As such, Nandy must find an intellectual strategy to subvert colonial rule in a way that would not simply replace a foreign pater familias with a domestic one. For this reason he is at pains to differentiate himself from the village habitants of the geographical hinterlands, stating that "they are quite capable of speaking for themselves." ${ }^{67}$ Rather, with these interventions Nandy seeks to reaffirm basic democratic principles by supporting the legitimacy of the epistemes that are organic to native hinterlands and which might even travel subversively with natives on the road to urban areas. ${ }^{68}$ It is less the geographical spaces and more the psychic hinterlands of tradition that Nandy is concerned with redeeming, specifically as a way to unsettle the modernist illusions of native-servants. Nandy's praxis of "critical traditionalism" ${ }^{69}$ is therefore designed to facilitate "a journey into the interiors of self, to search for resources that may allow one to transcend the limits set by our times." 70

Furthermore, through this praxis Nandy seeks to intimately subvert the relationship between the native and the freeman by replacing toleration with 
reconciliation. Locke tolerates indigenous faiths only in so far as their existence proves that natives are potentially able to receive truth per se. Nandy roundly criticises such paternalistic practices. He does so by revealing them to be fundamentally intolerant and violent. ${ }^{71}$ Freemen, so sure of their eschatological purpose, can live with "anything but an attenuated role". ${ }^{72}$ For this reason they never feel any mourning for the modes of life that they have displaced through colonization. ${ }^{73}$ And this is the reason why, for Nandy, the acts of violence emanating from the freeman's household have usually far surpassed those emanating from native villages. ${ }^{74}$

These subversive considerations impel a different sensibility to the relationship between the native / colonized and freeman / colonizer. ${ }^{75}$ Tolerance foisted upon non-believers by public displays and acknowledgements of the official gospel of the pater familias - as demanded in Locke's Carolina constitutions - must be put to one side. In its stead, an "apocryphal ear" must be developed. ${ }^{76}$ With the development of this faculty come two revelations. First, natives who seemingly make bad copies of the freeman's catechisms are in fact acculturating them to native traditions in order to heal the wounds delivered by the mission spirituelle. ${ }^{77}$ Second, colonial freemen are not at all public in their confessions, but have secret Indian lives too, wherein the burden of living as a super-human being is laid down. ${ }^{78}$ In other words, freemen deny their humanity by alienating that native part of themselves which their mission spirituelle demands them to destroy.

Against this disavowal of past/native lives in an escape to a pristine future, Nandy sketches out a different kind of utopia that instead seeks to critically redeem the ethical and practical possibilities of the hinterlands of tradition. ${ }^{79}$ Present suffering must be addressed by redemption of the past rather than ameliorated for the sake of imagined future progress. ${ }^{80}$ In this respect, the aspirant native-servant should have the self-confidence to put her critical thinking to internal use, rather than learn the violent ideology of improvement/industriousness in the household of the pater familias. This is why for Nandy utopia must essentially reside in the psyche as a "certain quality of thinking and living" rather than as a manifest totality. ${ }^{81}$ While Nandy's site of exposition is firmly India, he nevertheless offers this praxis to all those suffering under the colonial condition globally, and I shall return to this gesture shortly. 
In sum, Nandy subverts Locke's relation between the freeman and native in three ways. First, the eschatological narrative by which the freeman justifies future paternal rule over the wild native is undermined. Indeed, wilderness is enculturated with a relatable past ensconced in the rich hinterlands of traditions available even to native-servants. There can be no nature free to possess because it is already called India. Second, Nandy argues that the violence borne from the freeman's possessive accumulation should not be apprehended by the native as foreign to her innocent nature; rather, she must take accountability for that violence in order to actively attend to its healing. No paternalism is possible, not even an expectation that the pater familias must attend to his rightful duties; tolerance is thereby rendered meaningless. Third, because the architecture which supported the uniqueness of the freeman's household has now collapsed, the tenuous hinterlands of his own European society might come into vision, to be perhaps redeemed and reconciled with those of the colonized world. ${ }^{82}$ In short, the native and the freeman should reconcile so as to transform their relationship into something else.

What of Nandy's global gesture? At one point in his excursus on utopias, he takes Fanon to task for not reconciling with the freeman. Nandy admits that Fanon also works with the psyche as a possible hinterland, that is, a site of being other-wise. However, Fanon "calls for an exorcism in which the ghost outside has to be finally confronted in violence, for it carries the burden of the ghost within" ${ }^{83}$ Nandy chides Fanon for misapprehending the organized violence of colonial rule as a tool for liberation rather than as a culture of oppression. And from the preceding discussion it is easy to understand why: exorcising the colonial freeman is precisely the strategy by which native-servants become ersatz domestic freemen and so the redemption of hinterlands by this method is at the same time their obliteration. In Nandy's praxis, exorcism is the colonial completion of alienation from oneself and one's hinterland, whereas reconciliation redeems the hinterlands for the critical purpose of transforming the present rule of freemen. If only Fanon had had "more confidence in his [own] culture", he would have realised this. ${ }^{84}$

Nandy is correct about Fanon's self-confidence; as we shall see, he invested little hope in the cultures of the once-enslaved peasants of the Caribbean hinterlands. 
But Nandy's critique is nevertheless provincial. He has read the native as representative of the universal colonial condition. However, Fanon has to come to terms with the relationship between the freeman and negro slave, not that of the native. In this particular relation, the freeman is not just pater familias but pater familias rex: the intimacy of the negro slave to the colonial freeman is defined not by paternal tolerance but by the sovereign right of death in the face of which not even Christ will save. Indeed, in so far as natural law does not protect her from this complete domination, the negro slave is not even a human being. There is no potential to rise to the status of servant, hence this particular relation of being/non-being has no immanent potential for reconciliation. Moreover, the slave trade has torn peoples from their African hinterlands and deposited them upon the plantations of America. In this context, Fanon questions whether the descendents of slaves have managed to retain a psychical hinterland and he is pessimistic. Thus, exorcism of the freeman might be the only and necessary path to create a liberated psychical space in which negro slaves might personify and humanize themselves.

These anxieties form Fanon's starting point in Black Skins, White Masks: “the black is not a man", and where the "man" should be there instead lies "a zone of nonbeing". ${ }^{85}$ By Fanon's time, Martinique, his birthplace, now incorporated as a department of France itself, no longer legally supports the freeman's sovereign rights of life and death over the slave. But Fanon argues that in social and psychological terms the ex-slave has yet to be affirmed her rightful place as a human under natural law. The negro attempts to overcome the non-being inflicted through slavery by making epidermalized comparisons. ${ }^{86}$ That is to say, rather than toleration the thin hope for incorporation of ex-slaves into the freeman's household lies only in an impossible attempt to pass phenomenologically as white, and thus as human. The skin testifies to the inauthenticity of this hope.

In order to dispel this false hope, Fanon questions the presumption of psychoanalysis that all psyches must be compared to that of the pater familias. Instead, seeking to ground psychiatric method in the lived experience of the negro, Fanon argues that the determining relationship is really between colony and metropolis and not between child and father. ${ }^{87}$ These are the building blocks of Fanon's distinctive "sociogenic" approach. It is designed to directly address what 
Fanon assumes to be a colonial fact: not only the physical but the physic frontier too has been closed on the negro; they no longer have access to any viable hinterlands. Rather, the negro's psyche has been overdetermined -overwhelmed - by the colonial relation that situates the white freeman as human and the black slave/Antillean negro as, by comparison, non-human. Hence, unlike the native, there are no living pasts or alternative selves in the hinterlands of tradition that could be redeemed. Fanon's assumptions leave, therefore, only one subversive option left: to exorcise the sovereign dominion of the freeman from the psychic and social architecture of Antillean life; to exorcise the colonial relation itself; and through the necessary violence that this requires, to joyfully set afoot a brand new human being. ${ }^{88}$ Fanon's "new humanism" will be cultivated in a liberated zone, not an extant hinterland.

In light of Fanon's experience of Locke's architecture, Nandy's ethos of reconciliation reveals itself to be provincial rather than global. Nevertheless, Nandy's judgement still leaves Fanon with a challenge: where exactly might the Antillean negro find the resources through which to exorcise his non-being and create a liberated zone? Did the freeman, in the years of slavery, really destroy all the hinterlands? Did the plantation complex really flatten the psyche as well as the forests?

The history of rebellion and maroonage in Martinique would seem to indicate that Fanon is too hasty in this regard. Glissant, fellow Martiniquan, although notably pessimistic about the capacity of Antillean societies to self-determine nevertheless works with the trope of maroonage. He identifies present day hinterlands in language and folklore, precarious and on the verge of being overwhelmed by French paternal culture, yet still, extant and offering at least potential reservoirs to power selfdetermination. ${ }^{89}$ To this trope we should add a more generally observation that Black male Caribbean writers in the twentieth century have tended to fixate upon their absence in the white political society of colonial freemen; Black women writers, alternatively, have tended to look to the cultural resources of survival and resistance that have long dwelt in familial and personal hinterlands of enslaved communities and their descendants. ${ }^{90}$ Fanon shares this male fixation as well as its obfuscations when he admits that when it comes to the relationship between women of color and men of 
color, "I know nothing about her." 91 For all these reasons Fanon's lack of selfconfidence in the negro cultures of the Antilles is epistemically suspect.

Nevertheless, with no cultivation of a new human seemingly possible upon the barren rocks of the Antilles, Africa beckons Fanon as an energetic source through which to power an exorcism of Western Babylon. Once he has found his way abroad into the Free French army during the World War, Fanon comes across real-existing French African troops. Yet his regiment is billeted separately to them, even though his epidermis constantly confesses to Europeans that he is no different. ${ }^{92}$ So by the time he is writing Black Skins Fanon has come to realise that the impossible hope of becoming a servant is being kept alive by the acceptance amongst Antillean negroes of the image of continental Africans disseminated by the paternal culture of the political society of colonial freemen. ${ }^{93}$

In other words, so long as Antilleans can place themselves betwixt these "real" negroes - with their savagery, fetishism and tom-toms - and white Frenchmen, they can imagine themselves to be living in the house of the pater familias as good servants rather than as abject slaves. ${ }^{94}$ Fanon must cut and clear through this misapprehension. He clarifies for Antilleans that they are not between white and black but rather betwixt black and black. What is more, Antilleans cannot find solace in the original continental hinterlands because continental Africans themselves have proclaimed that there is no innate or primordial sharing of the African and Antillean psyche that might span the Atlantic. ${ }^{95}$ After "the great white error", the Antillean negro must now recognize that he is "living in the great black mirage", ${ }^{96}$

However, in making these critical movements, Fanon does not qualify his own Antillean praxis of exorcism but more so universalises its provenance. This is clearly evident in his address to the First Congress of Negro Writers in Paris 1956 (likened by one of its organizers to a "cultural Bandung"):

the memory of Nazism, the common wretchedness of different men, the common enslavement of extensive social groups, the apparition of 'European colonies', in other words, the institution of a colonial system in the very heart of Europe, the growing awareness of workers in the colonizing and racist countries, the evolution of 
techniques, all this has deeply modified the problem and the manner of approaching [racism]." 97

Here, Fanon argues that colonial racism has migrated from the visceral apprehension of individuals into assumptions and implicit judgements on culture and "certain forms of existing". ${ }^{98}$ Signified by the Shoah, the sovereign power of the freeman over the negro slave now threatens to mutate beyond law to incorporate all whose epidermis confesses a less-than human status. There are no hinterlands left anywhere. Exorcism of the colonial freeman - masquerading as human - must, therefore, be the global liberation strategy for putting afoot a new human. Precisely by globalising the ethos of exorcism Fanon begins to treats the natives of North Africa as if they are Antillean negro-slaves. Witness his resignation letter to the Resident Minister:

\footnotetext{
If psychiatry is the medical technique that aims to enable man no longer to be a stranger to his environment, I owe it to myself to affirm that the Arab, permanently an alien in his own country, lives in a state of absolute depersonalization. What is the status of Algeria? A systematized de-humanization. ${ }^{99}$
}

Thus, in Fanon's praxis, liberated zones replace tenacious hinterlands in a strikingly modernist vision. Yet at one point, Fanon tantalisingly invokes the mobile hinterlands of the Caribbean where, in protective and permissive drum circles, sufferers are possessed by the ancestral spirits, lose their "limits" and exorcise Babylon to "liberate" themselves. ${ }^{100}$ Could it be, then, that exorcism might work to redeem living African pasts rather than brand new futures? Fanon evades the provocation because for him these hinterlands are neither authentic nor living. Africa - and America, even perhaps India - exist only as elegiac memories of what has been callously destroyed by colonial rule. ${ }^{101}$ Fanon's is therefore an instrumental appreciation of the cultural detritus leftover from the closing of psychic frontiers; by happenstance the outrage that accompanies a deep sense of loss could produce in the native a realization of self-agency that, channelled positively, would lead to an exorcism of the freeman's colonial rule and the crafting of a new architecture of humanity. ${ }^{102}$ 
We are left with an abiding friction in Fanon's praxis. As a psychiatrist, Fanon is working from the standpoint of the negro (ex-)slave and is seeking to exorcise the despotic freeman from his psyche. His praxis of exorcism is, as I have intonated, by necessity a profoundly positive one. Negros, as non-beings, must entirely liberate themselves from the colonial relation. But Fanon is clear that in doing so, their necessarily violent methods must not lead to replication of the sovereign rule of the pater familias-rex; redolent of Nandy's concerns, Fanon suggests that the wretched of the earth must also help white freemen to weave for themselves a new humble skein of humanity. ${ }^{103}$ Nevertheless, the price of Fanon's radically transformative and positive praxis is a phenomenological erasure of the precarious and long defended hinterlands of both (African) natives and (Antillean) negroes. Fanon seeks to carve out liberated zones; he is not interested in caring for prior inhabitations. Does Fanon accept too much of Locke's architecture at face value? Lest we forget, exorcism is a binding oath to evict a demonic presence; it is not an oath to evict all presence.

And what of Nandy? He has no wish to represent the geographical hinterland the villages of India. He is focused, instead, on transforming the native/freeman relationship by legitimising the pasts and other selves that emanate from the more mobile psychical hinterlands of tradition. A psychiatrist, Nandy has situated himself within the freeman's household as a traitorous native-servant that subverts his master's toleration. There, he seeks first and foremost to reconcile both the nativeservant and the (new and old) pater familias to the hinterlands of tradition that surround them. Seeking to draw attention to the pathologies of inhabiting the centre of Locke's colonial architecture, Nandy replies to his native-servant critics that tradition per se "is a toothless tiger now"; it is much more important, he argues, to criticize the violence emanating from the household that one occupies rather than the native villages one has sought to leave behind. ${ }^{104}$ This is also why Nandy proclaims that negatively defined utopias are better than positively defined ones. ${ }^{105}$ The praxis is a careful one. But is it really redemptive if there is no conviction, no positivity, no joy no Felicity - to be garnered from the Indian past?

\section{By Way of Conclusion: Relatable Hinterlands and the Spirit of Bandung}


Colonial rule, as formulated by Locke, is dispensed from the freeman's house and radiates outwards in myriad directions to ensnare and enclose aliens and subalterns, to close the frontier and dissolve those hinterland spaces - psychical, geographical and epistemic. Opposing this colonial architecture stands Fanon, whose anger has been so profoundly contagious on a global scale. After all, toleration is a ruse that hides genocidal tendencies, and behind the mask of every pater familias lurks the genocidal pater familias rex. No wonder so many natives - and their intellectual representatives - have shared Fanon's joy at the prospects of exorcising the freeman to inaugurate the dawning of a new humanity. ${ }^{106}$ Nandy's care for reconciliation is less infectious. In some ways, he expects far too much from the pater familias. Nevertheless, Nandy reminds Fanon of a reality so subtle that it can be easily overlooked in the forging of a brand new humanity: hinterlands are far more tenacious than the freeman has supposed - even in the native psyches of negro slaves.

Read as part of the History of Bandung, Fanon's project of exorcism has been crushed by the ever expanding architecture of post-colonial rule, while the fate of Nandy's project of reconciliation has been that of incorporation. Perhaps these were always provincial projects that would never be able to match the globality of Locke's architecture. And yet, retrieval of Nandy and Fanon's projects through the memory of Bandung ${ }^{107}$ reveals something else. Here, their fates are not determined by the sequential domination of the freeman but are rather opened up to decolonial alternatives through a generative seedbed of relationality, albeit one that is currently hidden under the postcolonial term for possessive accumulation: "South-South trade". Apprehended through the memory of Bandung, Fanon provides the anti-colonial impulse and Nandy the decolonial sensibility. Their crossing enlivens the spirit of Bandung that proselytises a logic of solidarity other-wise to the post-colonial condition: the negro slave is the potential future of all of the freeman's subjects; but the slave, like all others, has a native hinterland to redeem.

This, I submit, is the spirit of Bandung: hinterlands made relational for the pursuit of decolonial alternatives. The provocation that this thought piece makes, therefore, is that we should be thinking politically around the possibility of relatable hinterlands and not only dwelling upon the operations of a global postcolonial architecture. After all, the wretched of the earth have always had to rudely criss-cross 
the paths laid down by colonial rule to retrieve extant passages and to burn new ones. Sometimes, in the course of journeying, the epics of India resonate with the chants to Africa-Zion. These journeys and crossings are not recorded in colonial History nor in the trace of postcoloniality. In their apocryphal testimony lies the prospect that the native, negro and freeman might cease to be, while hinterlands might become, simply, lands.

\section{Notes}

${ }^{1}$ Derek Walcott, "The Antilles: Fragments of Epic Memory," 1992, http://www.nobelprize.org/nobel_prizes/literature/laureates/1992/walcott-lecture.html.

${ }^{2}$ Congo Rocky, "Nyahbinghi Elders Address Issembly," Jahug 2, no. 2 (1992): 56.

${ }^{3}$ Édouard Glissant, Caribbean Discourse: Selected Essays (Charlottesville: University Press of Virginia, 1989); and for an indigenous perspective see Glen Coulthard, "Place Against Empire: Understanding Indigenous Anti-Colonialism," Affinities 4, no. 2 (2010): 79-83.

${ }^{4}$ see also Cedric Robinson, Black Marxism: The Making of the Black Radical Tradition (London: University of North Carolina Press, 2000), 310.

${ }^{5}$ See Dipesh Chakrabarty, "Legacies of Bandung: Decolonisation and the Politics of Culture," Economic and Political Weekly 40, no. 46 (November 12, 2005): 4812-4818; Robert Young, "Postcolonialism: From Bandung to the Tricontinental," Historein 5 (2005): 11-21; Walter Mignolo, The Darker Side of Western Modernity: Global Futures, Decolonial Options (Durham: Duke University Press, 2011), xxiii; Vijay Prashad, The Darker Nations: A People's History of the Third World (New York: New Press, 2007).

${ }^{6}$ See in general Matthew Jones, "A 'Segregated' Asia?: Race, the Bandung Conference, and PanAsianist Fears in American Thought and Policy, 1954-1955," Diplomatic History 29, no. 5 (2005): 841-68.

${ }^{7}$ See for example Partha Chatterjee, "Empire and Nation Revisited: 50 Years after Bandung," InterAsia Cultural Studies 6, no. 4 (2005): 488; Kinhide Mushakoji, "Resisting Global Hegemony," in Eurasia, ed. M.D. Intriligator, A.I. Nikitin, and M. Tehranian (Bingley: Emerald Group Publising, 2005), 53-65; Christopher J. Lee, "At the Rendezvous of Decolonization," Interventions: International Journal of Postcolonial Studies 11, no. 1 (2009): 86-87.

${ }^{8}$ Robert Vitalis, "The Midnight Ride of Kwame Nkrumah and Other Fables of Bandung (BanDoong)," Humanity: An International Journal of Human Rights, Humanitarianism, and Development 4, no. 2 (2013): 261-88; see also Prashad, The Darker Nations: A People's History of the Third World, 34 .

${ }^{9}$ Mustapha K. Pasha, “The 'Bandung Impulse' and International Relations," in Postcolonial Theory and International Relations (Abingdon: Routledge, 2013), 155; Rémy Herrera, "Fifty Years after the Bandung Conference: Towards a Revival of the Solidarity between the Peoples of the South? Interview with Samir Amin," Inter-Asia Cultural Studies 6, no. 4 (2005): 547; Chatterjee, "Empire and Nation Revisited."

${ }^{10}$ Young, "From Bandung to the Tricontinental," 14-15; Lee, "At the Rendezvous of Decolonization," 88.

${ }^{11}$ See in general Randolph B. Persaud, "Reconceptualizing the Global South's Perspective: The End of the Bandung Spirit," in The Foreign Policies of the Global South: Rethinking Conceptual Frameworks, ed. J.A. Braveboy-Wagner (Boulder: Lynne Rienner, 2003), 49-64. Pasha, "Bandung Impulse," 152; Chatterjee, "Empire and Nation Revisited"; Chakrabarty, "Legacies of Bandung."

${ }^{12}$ Robbie Shilliam, "Civilization and the Poetics of Slavery," Thesis Eleven 108, no. 1 (February 1, 2012): 99-117.

${ }^{13}$ Pasha, "Bandung Impulse," 154; see also Charlie Samuya Veric, "Third World Project, or How Poco Failed," Social Text 31, no. 1114 (2013): 1-20.

${ }^{14}$ Mignolo, The Darker Side of Western Modernity.

${ }^{15}$ For example, Kuan-Hsing Chen, "Introduction: The Decolonization Question," in Trajectories: Inter-Asia Cultural Studies, ed. Kuan-Hsing Chen (London: Routledge, 1998), 1-48; Arif Dirlik, "Reading Ashis Nandy: The Return of the Past; or Modernity With a Vengeance," in Dissenting 
Knowledges, Open Futures: The Multiple Selves and Strange Destinations of Ashis Nandy (Oxford: Oxford University Press, 2000).

${ }^{16}$ e.g. C Macpherson, The Political Theory of Possessive Individualism: Hobbes to Locke (Oxford: Clarendon Press, 1964); Ellen Meiksins Wood and Neal Wood, A Trumpet of Sedition: Political Theory and the Rise of Capitalism, 1509-1688 (Washington Square, N.Y: New York University Press, 1997), 112-134.

${ }^{17}$ John Locke, Two Treatises of Government (London: J.M. Dent, 1993), 116.

${ }^{18}$ Ibid.

${ }^{19}$ Ibid., $125-126$.

${ }^{20}$ Ibid., 117, 124.

${ }^{21}$ Ibid., 128 .

${ }^{22}$ Herman Lebovics, "The Uses of America in Locke's Second Treatise of Government," Journal of the History of Ideas 47, no. 4 (October 1, 1986): 572.

${ }^{23}$ William G. Batz, "The Historical Anthropology of John Locke," Journal of The History of Ideas 35, no. 4 (1974): 663-670.

${ }^{24}$ Locke, Two Treatises of Government, 128 see also 122, 129, ; see also Lebovics, "Uses of America," 568

25 "The Ideological Commitment of Locke: Freemen and Servants in the Two Treatises of

Government," History of Political Thought 13, no. 4 (1992): 631-656.

${ }^{26}$ AUTHOR REDACTED

${ }^{27}$ Locke, Two Treatises of Government, 140.

${ }^{28}$ Ibid., 157.

${ }^{29}$ Ibid., 115, 153

${ }^{30}$ Ibid., 129 (my emphasis).

${ }^{31}$ Ibid.

${ }^{32}$ Ibid., 135, 139.

${ }^{33}$ Ibid., 129-132.

${ }^{34}$ Ibid., 132.

${ }^{35}$ Ibid., 137.

${ }^{36}$ Ibid., 139.

${ }^{37}$ see Lebovics, "Uses of America," 575-577.

${ }^{38}$ Locke, Two Treatises of Government, 131.

${ }^{39}$ See Kamil Shah and Heloise Weber, "Saving the Natives From Idleness: Questioning the Historical Universality of a Labouring Self” (presented at the International Studies Association Annual

Conference, Montréal, 2011).

${ }^{40}$ H. R. Fox Bourne, The Life of John Locke (New York: Harper \& Brothers, 1876), 378.

${ }^{41}$ reproduced in ibid., 379.

${ }^{42}$ Ibid., 380.

${ }^{43}$ See for example John Locke, "Fundamental Constitutions of Carolina," in Political Writings, ed.

David Wooton (London: Penguin, 1993), 228.

${ }^{44}$ See also Jack Turner, "John Locke, Christian Mission, and Colonial America," Modern Intellectual History 8, no. 2 (2011): 293.

45 "Women as Wives, Servants and Slaves: Rethinking the Public/Private Divide," Canadian Journal of Political Science 34, no. 1 (2001): 29-54.

${ }^{46}$ Locke, Two Treatises of Government, 156; see also E.J. Hundert, "The Making of Homo Faber: John Locke Between Ideology and History," Journal of the History of Ideas 33, no. 1 (1972): 17; Arneil, "Women as Wives, Servants and Slaves," 365.

${ }^{47}$ Hundert, "Making of Homo Faber," 5-7.

${ }^{48}$ see Turner, "John Locke, Christian Mission," 295.

${ }^{49}$ see especially John Locke, “A Letter Concerning Toleration,” in Political Writings, ed. David

Wooton (London: Penguin, 1993), 416-417.

${ }^{50}$ Ibid., 228.

51 Turner, "John Locke, Christian Mission,” 293.

${ }^{52}$ Lebovics, "Uses of America," 578.

${ }^{53}$ Locke, Two Treatises of Government, 156-157.

${ }^{54}$ James Farr, "Locke, Natural Law, and New World Slavery," Political Theory 36, no. 4 (August 1, 2008): 501-502.

55 Ibid., 504.

${ }^{56}$ Locke, "Fundamental Constitutions of Carolina," 230. 
57 Ibid.

${ }^{58}$ Ashis Nandy, "Elements of Modernity Are Oppressive," The Sunday Statesman Magazine, May 9 , 2004, http://www.fize.de/pdf/f.ize_nandy.pdf.

${ }^{59}$ Ashis Nandy, The Intimate Enemy: Loss and Recovery of Self Under Colonialism (Delhi: Oxford, 1983), 73.

${ }^{60}$ Ibid., 76.

${ }^{61}$ Ashis Nandy, "Modernity and the Sense of Loss, or Why Bhansali's Devdas Defied Experts to

Become a Box Office Hit," Inter-Asia Cultural Studies 12, no. 3 (2011): 447.

${ }^{62}$ Ibid.

${ }^{63}$ Ashis Nandy, An Ambiguous Journey to the City: The Village and Other Odd Ruins of the Self in the Indian Imagination, vol. A Very Popular Exile (New Delhi: Oxford University Press, 2007), 75.

${ }^{64}$ Nandy, "Modernity and the Sense of Loss," 445-446.

65 Ibid., 449.

${ }^{66}$ Nandy, "Elements of Modernity Are Oppressive."

${ }^{67}$ Nandy, "Modernity and the Sense of Loss," 450.

${ }^{68}$ Recent controversies over Nandy’s comments on Dalit rights brings these democratic principles partially into question.

${ }^{69}$ Ibid., 449.

70 Ibid., 445.

${ }^{71}$ Nandy, "Elements of Modernity Are Oppressive."

${ }^{72}$ Nandy, The Intimate Enemy, 102.

${ }^{73}$ Nandy, "Elements of Modernity Are Oppressive."

${ }^{74}$ See for example, Ashis Nandy, "Telling the Story of Communal Conflicts in South Asia: Interim Report on a Personal Search for Defining Myths," Ethnic and Racial Studies 25, no. 1 (2002): 1-19; Nandy, An Ambiguous Journey to the City, A Very Popular Exile:98-139.

${ }^{75}$ See Naeem Inayatullah and David L. Blaney, International Relations and the Problem of Difference (New York: Routledge, 2004), 165-169.

${ }^{76}$ Ashis Nandy, Traditions, Tyranny, and Utopias: Essays in the Politics of Awarenes; in A Very Popular Exile (New Delhi: Oxford University Press, 2007), 18.

${ }^{77}$ See, for example, Nandy's essay on Girindrasekhar Bose in The Savage Freud and Other Essays on Possible and Retrievable Selves (Princeton N.J.: Princeton University Press, 1995).

${ }^{78}$ See Nandy's famous commentary on Kipling in The Intimate Enemy.

${ }^{79}$ Put into practice see D. Blaney and N. Inayatullah, International Relations and the Problem of Difference (London: Routledge, 2004), chap. 5.

${ }^{80}$ Nandy, Traditions, Tyranny, and Utopias, 19-21.

${ }^{81}$ Ibid., 6-13.

${ }^{82}$ See for example, Nandy, "Telling the Story," 2.

${ }^{83}$ Nandy, Traditions, Tyranny, and Utopias, 33.

${ }^{84}$ Ibid., 34.

${ }^{85}$ Frantz Fanon, Black Skin, White Masks (London: Pluto Press, 1986), 10.

${ }^{86}$ Ibid., 212.

${ }^{87}$ Ibid., 141-145.

88 Ibid., 222.

${ }^{89}$ See, suggestively, Diva Barbaro Damato, "The Poetics of the Dispossessed," World Literature Today 63, no. 4 (1989): 606-608.

${ }^{90}$ June Roberts, Reading Erna Brodber: Uniting the Black Diaspora Through Folk Culture and

Religion (Westport: Praeger Publishers, 2006), 5-6, 33, 59.

${ }^{91}$ Fanon, Black Skin, White Masks, 179-180.

${ }^{92}$ See in general, David Macey, Frantz Fanon: A Biography (New York: Picador USA, 2001), 110.

${ }^{93}$ Frantz Fanon, "West Indians and Africans," in Toward the African Revolution (London: Penguin, 1970), 29.

${ }^{94}$ Fanon, Black Skin, White Masks, 148.

${ }^{95}$ Fanon, "West Indians and Africans," 34-35.

96 Ibid., 37.

${ }^{97}$ Frantz Fanon, "Racism and Culture," in Toward the African Revolution (New York: Grove Press, 1969), 42.

${ }^{98}$ Ibid.

${ }^{99}$ Frantz Fanon, "Letter to the Resident Minister 1956," in Toward the African Revolution

(Harmondsworth: Penguin, 1970), 63. 
${ }^{100}$ Frantz Fanon, The Wretched of the Earth (New York: Grove Press, 1968), 57.

${ }^{101}$ See for example Fanon's comments on Aztec civilization and Mexicans; Ibid., 209.

${ }^{102}$ Frantz Fanon, A Dying Colonialism (New York: Grove Press, 1967), 32.

103 Ibid.

${ }^{104}$ Nandy, "Elements of Modernity Are Oppressive."

105 Nandy, Traditions, Tyranny, and Utopias, 13.

${ }^{106}$ See for example Glen S. Coulthard, "Subjects of Empire: Indigenous Peoples and the 'Politics of Recognition' in Canada," Contemporary Political Theory 6 (2007): 437-60; E. Tuck and K. Wayne Yang, "Decolonization Is Not a Metaphor," Decolonization: Indigeneity, Education \& Society 1, no. 1 (2012), decolonization.org/index.php/des/article/download/18630/15554; and Haunani Kay Trask, "The Color of Violence," Social Justice 31, no. 4 (2004): 8-16; but see also Teresia Teaiwa, "Black in the Blue Pacific," The Other Voices International Project 3 (2004),

http://othervoicespoetry.org/vol3/teaiwa/index.html.

${ }^{107}$ Pasha, "The 'Bandung Impulse' and International Relations," 